\title{
Comparison of lucerne silage and ventilated hay in maize silage-based rations for dairy cows for the production of milk destined for Grana cheese
}

\author{
G. Colombari*, G. Borreani† and G. M. Crovetto $\ddagger$ \\ *Istituto Superiore Lattiero Caseario di Mantova, Regione Lombardia, Mantua, Italy, †Dipartimento Agronomia \\ Selvicoltura e Gestione del Territorio, Università di Torino, Italy, and łlstituto di Zootecnia Generale, Facoltà di \\ Agraria, Università di Milano, Milan, Italy
}

\begin{abstract}
Three experiments were carried out to study the effects of feeding lucerne silage (wilted to give different drymatter (DM) contents) and ventilated hay to dairy cows on milk production, milk quality, milk-renneting properties, clostridial spore content and the quality of cheese prepared from the milk. The lucerne, cut at vegetative or early-bud stages of maturity, was harvested from alternate windrows and conserved as silage or artificially dried hay. The lucerne was wilted until it reached different DM contents of 550, 360 and $432 \mathrm{~g} \mathrm{~kg}^{-1}$ in the three experiments, harvested, chopped with a selfloading forage wagon and ensiled in low and narrow clamps made up of transferable prefabricated walls. The organic acid content, $\mathrm{pH}$, yeast and mould counts of the lucerne silage suggested that there was no aerobic deterioration.

In each experiment, fifty Italian Friesian lactating cows were divided into two groups and fed two maize silage-based rations for 6 weeks, which only differed in the lucerne forage [silage (S) vs. ventilated hay $(\mathrm{H})$ ], in a cross-over experimental design. The lucerne in the rations represented $35 \%, 23 \%$ and $24 \%$ of the DM of the rations for the three experiments. The microbiological profiles of the ration were influenced more by the maize silage than by the lucerne silage.

Individual daily DM intakes were similar for the two treatments in Experiments 1 and 3 (on average 18.7 kg in Experiment 1 and $20.3 \mathrm{~kg}$ in Experiment 3) and slightly lower for $\mathrm{S}$ cows in comparison to $\mathrm{H}$ cows in Experiment $2(18.0 \mathrm{vs} .19 \cdot 0 \mathrm{~kg})$. Milk yields of $\mathrm{S}$ and $\mathrm{H}$
\end{abstract}

Correspondence to: Dr G. Borreani, Dipartimento Agronomia Selvicoltura e Gestione del Territorio, Università di Torino, via Leonardo da Vinci, 44, 10095 - Grugliasco, Torino, Italy. E-mail: borreani@agraria.unito.it

Received 3 August 1998; revised 17 November 1998 cows were 21.0 and $20.8,20.0$ and $20.6(P<0.01)$, and 28.4 and $27.9 \mathrm{~kg} \mathrm{~d}^{-1}$ in Experiments 1, 2 and 3 respectively. Milk composition was similar for all the experiments for the two treatments, except that the protein content was lower and the fat content was higher in the silage treatment than in the hay. The renneting properties and microbiology of the milk were not influenced by the introduction of lucerne silage into the rations, although the season in which it was consumed had a greater effect on the microbiological content, in terms of standard bacterial counts, proteolytic, coli and lactic acid bacteria, and clostridia spores. The clostridial spore counts were always very low $(<400$ per litre), thus fulfilling the requirements for top-quality milk for Grana cheese production. In the third experiment, the quality of Grana Padano cheese produced was examined, and no differences between treatments were observed after 12 months of maturation.

These results show that lucerne silage can be included in the ration of dairy cows instead of ventilated lucerne hay, which is considered to be the top-quality hay available for the production of milk destined for Grana cheese, without any negative effects on milk and cheese quality.

\section{Introduction}

To maximize the dry-matter (DM) intake of dairy cows and, consequently, milk yield, rations with a low fibre and with a rapidly digestible organic matter (OM) content are recommended (Paterson et al., 1994). On the other hand, environmental nitrogen $(\mathrm{N})$ pollution by intensive farming systems, as well as feeding costs, can be significantly reduced by systems where most of the feed is home grown following the use of rotations and the choice of particular forage species that guarantee a balance between $\mathrm{N}$, phosphorus and potassium inputs and outputs (Tamminga, 1992; 1996). Forages 
with a high $\mathrm{N}$ content can therefore be successfully produced on farm, together with high energy/low protein forage (e.g. maize silage) in order to obtain rations with a high forage proportion and well balanced in terms of protein and energy supply.

Legumes can contribute to sustainable farming systems because of their capability to fix $\mathrm{N}$, and their potentially high nutritional value (Sprent and 't Mannetje, 1996). Lucerne is of interest because of its low neutral-detergent fibre content (NDF), its high degradation rate and high protein content, compared with grasses (Marten et al., 1988; Wilman et al., 1996). A further improvement in the nutritive value of lucerne can be obtained by earlier cutting (Borreani et al., 1996). However, earlier cuts prolong the drying period (Acutis et al., 1994) and therefore increase the probability that the forage will be exposed to rainfall. In these situations, ensiling or artificial drying techniques are particularly advantageous because the exposure of the forage in the field is limited to a very short time. They are thus less weather dependent with drastically reduced mechanical losses compared with traditional haymaking. Ensiling requires less capital and incurs lower running costs than artificial drying techniques (Marsh, 1979), but can cause microbial stability problems during silage consumption (Woolford, 1990). Even though artificial drying results in microbiologically stable forages and hampers proteolysis, it causes serious logistic problems in harvesting.

For successful fermentation, lucerne should have a DM content higher than $350 \mathrm{~g} \mathrm{~kg}^{-1}$ fresh matter (FM) at ensilage, owing to its low water-soluble carbohydrate content and high buffering capacity (Ciotti et al., 1985). Ensiling at values of DM content around $500 \mathrm{~g} \mathrm{~kg}^{-1} \mathrm{FM}$ maximizes the DM intake of dairy cows (Van Vuuren et al., 1995) and reduces the nitrogen transformations because of plant enzyme activity and microbial degradation (Muck, 1987) but increases the risks of aerobic deterioration as a result of the higher porosity of the silage (Williams et al., 1994).

In addition, the high non-protein nitrogen (NPN) content of lucerne silage, which usually ranges from $50 \%$ to $87 \%$ of total N (Broderick, 1995), produces a higher content of soluble protein and a higher rumen degradation rate of $\mathrm{N}$ in lucerne silage than in hay (Makoni et al., 1994). Degradation of digestible protein in excess of microbial needs results in elevated ruminal ammonia concentrations (most excess ammonia is absorbed and then excreted in the urine as urea) and in inefficient utilization of lucerne protein, which may lower milk and protein yields (Broderick, 1985).

High rates of DM digestion in the rumen are generally welcome in dairy ration formulation, in order to maximize rumen turn-over and feed intake, which are positively correlated with milk production: in this respect lucerne silage is superior to lucerne hay (Nelson and Satter, 1992a).

The use of silages in rations for lactating cows can be detrimental to the quality of milk destined for hard and semihard cheese production (Annibaldi, 1969; Gouet and Bergère, 1973; Colombari and Fantuzzi, 1991). Clostridia spores from highly contaminated silages may pass into the milk (Stadhouders and Spoelstra, 1990) via dung contamination, even if good hygienic milking conditions are practised (Stadhouders and Jørgensen, 1990). They survive milk pasteurization and pass unaffected into the cheese where they can cause the so-called 'late blowing' defect.

The aim of this research was to compare, at farm scale, over the whole cycle from forage to cheese, the qualitative characteristics of lucerne silage wilted at different moisture contents with ventilated lucerne hay (chosen as a top-quality hay available on the farm) and their influence on milk production, milk-renneting properties and the quality of Grana Padano cheese.

\section{Materials and methods}

\section{Crop and silages}

Three experiments were carried out at the experimental farm of the Istituto Superiore Lattiero Caseario of Mantova $\left(45^{\circ} 09^{\prime} \mathrm{N}, 10^{\circ} 48^{\prime} \mathrm{E}\right)$ in the Po Valley on three different cuts of lucerne (Medicago sativa L.) cvs. Delta and Boreal, grown in a soil with a texture of $30 \%$ clay, $40 \%$ silt and $30 \%$ sand.

All the forages, mown at a stubble height of $4 \mathrm{~cm}$ and conditioned, were left in swaths and tedded after 3-4 h of wilting. The weather during wilting was always good and the forages were harvested from alternate windrows: half after one day of wilting with a self-loading forage wagon (Kemper Cargo L 9000, Stadtloon, Germany), set to a chop length of $40 \mathrm{~mm}$, and then ensiled in low, narrow clamps made up of transferable prefabricated $0.9 \mathrm{~m}$ high walls that were spaced $4.0 \mathrm{~m}$ apart; half after 2 days of wilting at least at a DM content of $550-600 \mathrm{~g} \mathrm{~kg}^{-1}$ FM and then artificially dried using an on-farm drying system with drying chamber of $8 \mathrm{~m} \times 10 \mathrm{~m} \times 5 \mathrm{~m}$ dimensions and with a batch capacity of about $40 \mathrm{t}$.

The silage was carefully compacted with a tractor, covered with two films of polyethylene and weighted down with $100 \mathrm{~kg} \mathrm{~m}^{-2}$ of sand. The feed-out rate of lucerne silage was in the range of $25-30 \mathrm{~cm} \mathrm{~d}^{-1}$. The hay was stored loose until feed-out.

In the three experiments the whole crop maize silage was produced from a maize crop (Zea mais L. cV. Costanza, FAO class 600) sown between 18 and 25 May, harvested at the dough-ripe stage with a precision-chop forage harvester and ensiled in bunker silos with $2 \cdot 7$-m-high walls, spaced $6.0 \mathrm{~m}$ apart. 


\section{Chemical and microbiological analyses of forages}

Samples of herbage at cutting and hay were analysed for DM content by oven drying at $90^{\circ} \mathrm{C}$ until a constant weight was achieved, crude protein $(\mathrm{CP}=$ Kjeldahl $\mathrm{N} \times 6 \cdot 25)$, ash by ignition to $550^{\circ} \mathrm{C}, \mathrm{NDF}$ and aciddetergent fibre (ADF) by the sequential analysis of Goering and Van Soest (1970) measured on an ash-free basis.

Silage sampling for chemical and microbiological analyses was made weekly during feeding, by coring (diameter $5 \mathrm{~cm}$ ) at $30 \mathrm{~cm}$ deep inside the mass of the silage in four different parts of the front of the silo (Figure la-d). The decision to consider separately the most external zones of the silo derives from the fact that in these small clamps the peripheral zone (up to $20 \mathrm{~cm}$ depth) represents a considerable part (about 20\%) of the whole volume, hence the importance of studying the fermentative and microbiological aspects of the external areas of the silage mass for a better understanding of animal performance.

Aqueous extracts (with water for $24 \mathrm{~h}$ at $4^{\circ} \mathrm{C}$ ) were analysed to determine $\mathrm{pH}$, total $\mathrm{N}$ and ammonia- $\mathrm{N}$ concentration determined using the method of Byrne and Power (1974). Soluble $\mathrm{N}$ was determined in a phosphoborate buffer at $\mathrm{pH} 6.8$ and $39^{\circ} \mathrm{C}$ for $1 \mathrm{~h}$ (Krishnamoorthy et al., 1982). Lactate, acetate and butyrate were determined as described by Canale et al. (1984).

Microbiological analyses of clostridial spores were made according to the most probable number (MPN) technique with lactate-acetate agar (Spoelstra, 1984) after 7 days of incubation at $37^{\circ} \mathrm{C}$, and colony-forming units (CFU) of yeasts and moulds were enumerated using the pour plate technique with $40.0 \mathrm{~g} \mathrm{l}^{-1}$ of yeast extract glucose chloramphenicol agar (YGC agar, DIFCO, West Molesey, Surrey, UK) after 3 days of incubation at $25^{\circ} \mathrm{C}$.

Silage density was calculated by measuring the corer volume and the weights of the samples.

\section{Animals and management}

The three experiments were carried out using Italian Friesian lactating cows divided into two groups of

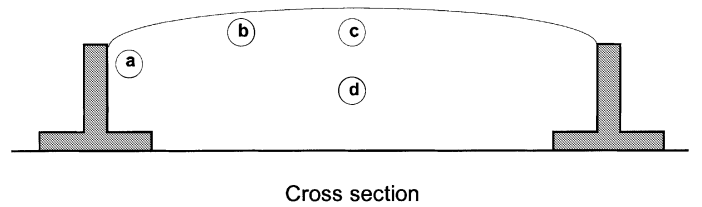

Figure I Sampling scheme of the lucerne silage. The shaded areas represent the silo walls. twenty-five animals each. At the beginning of Experiments 1, 2 and 3 the two groups of cows were balanced, as far as possible, between the silage and the hay treatment for parity $(2 \cdot 6,2 \cdot 6$ and $2 \cdot 5$ lactations), stage of lactation (166, 160 and 138 days post partum) and individual daily milk yield $(21 \cdot 6,21 \cdot 5$ and $28 \cdot 8 \mathrm{~kg})$. About half of the animals present in Experiment 1 were present in Experiment 3.

A cross-over design was used. Each experiment lasted 12 weeks: 2 weeks of adaptation followed by 4 experimental weeks for each of the two phases. The rations, as total mixed rations (TMR), were always offered in the morning. The forage proportion of the TMR included lucerne silage or hay, maize silage and some grass hay (Table 5).

At the beginning of each adaptation period, the rations were fed to meet the predicted maintenance and production requirements, but adjustments of the quantity of the TMR offered to each group were made according to appetite. Drinking water was available ad libitum. Experiments 1, 2 and 3 were conducted in winter, summer and spring respectively.

\section{Intakes and ration analyses}

The DM intake was recorded daily for each group of cows. Every morning, before feeding, the refusals were collected, weighed and analysed for DM content, in order to measure the actual DM intake of each group. Three times each week, during the experimental periods, the TMR fed to each group of cows was sampled and analysed for $\mathrm{CP}, \mathrm{NDF}$, ash, clostridia spores and yeasts. Net energy for lactation (NEL) was calculated by the equations proposed by Andrieu and Demarquilly (1987).

\section{Faecal analyses}

Samples of faeces were also collected directly three times each week from two cows of each group after the afternoon milking to determine the concentration of clostridia spores.

\section{Milk and cheese analyses}

The milk yield, milk fat, protein and lactose contents, and the somatic cell count (SCC) of individual cows were recorded twice each week. Milk yield was recorded from both milkings, whereas individual milk composition was determined on the milk from the morning milking. The interval between milkings was always $12 \mathrm{~h}$. The bulk milk of each group of cows was analysed three times each week for microbiological characteristics [standard bacterial count (SBC), proteolytic, coli and lactic acid bacteria, and clostridia spores], 
nitrogenous fractions (urea $\mathrm{N}$, whey protein $\mathrm{N}$, nonprotein $\mathrm{N}$, caseinic $\mathrm{N}$ ), and acidity and renneting properties $[r=$ time required to start clotting (min); $k_{20}=$ time $(\mathrm{min})$ to reach a standard clot consistency (20 $\mathrm{mm}$ at the trombelastograph tracing); $a_{30}=$ consistency of the clot after $30 \mathrm{~min}$ from the beginning of clotting ( $\mathrm{mm}$ of the trombelastograph tracing; Tarodo de la Fuente et al., 1969)].

The quality of the Grana Padano cheese produced from the milk in Experiment 3 was checked after 12 months of maturation in order to evaluate the influence of treatment. The evaluation of cheese quality was carried out by an expert from the Grana Padano Consortium. Cheese that presented fermentation damage was analysed by gas chromatography (Contarini et al., 1989) to identify the microbiological source of the damage.

\section{Statistical analysis}

The significance of the differences of the treatments for milk yield, milk fat, protein, lactose and SCC contents in each experiment was examined using the following cross-over model with a GLM procedure (SAS Institute, 1994):

$$
Y_{i j k}=\mu+P_{i}+C_{j}+T_{k}+e_{i j k}
$$

where $Y_{i j k}=$ dependent variable; $\mu=$ general mean; $P_{i}=$ period effect $(i=1-2) ; C_{j}=$ cow effect $(j=1-25)$; $T_{k}=$ type of conservation of the lucerne $(k=1-2) ; e_{i j k}$ $=$ error. The interactions between period and treat- ment, and period and cow were not significant and therefore were not included in the model.

The data from the three experiments on the chemical-microbiological characteristics of the bulk milk (acidity, $r, k_{20}, a_{30}, \mathrm{SBC}$, proteolytic and lactic acid bacteria and clostridial spores), the nitrogenous fractions and the data on the spore content of the faeces were analysed using the following model:

$$
Y_{i j k}=\mu+P_{i}+T_{j}+e_{i j k}
$$

where $Y_{i j k}=$ dependent variable; $\mu=$ general mean; $P_{i}=$ period effect $(i=1-2) ; T_{j}=$ type of conservation of the lucerne $(j=1-2) ; e_{i j k}=$ error. SCC data were first converted into linear scores $\left(\mathrm{LS}=\log _{2}(\right.$ cells/12 500)) because of their non-normal distribution. Similarly, the microbiological data on the feeds, faeces and milk were first transformed to $\log _{10}$.

\section{Results and discussion}

\section{Lucerne herbage quality}

The date of cutting, yield, morphological stage of the crop, days of conservation and the period of consumption for the three experiments are reported in Table 1.

In all the experiments the lucerne was cut at an early stage (vegetative in the first and second, and early bud in the third). The main qualitative characteristics of the herbage at cutting, silages at feed-out and artificially dried hays are reported in Table 2 . The early cutting permitted low NDF and high CP contents in the forage,

Table I Date of cutting, yield, stage, and days of lucerne silage conservation in the three experiments.

\begin{tabular}{lccc}
\hline & \multicolumn{3}{c}{ Experiment } \\
\cline { 2 - 4 } & $\mathbf{1}$ & $\mathbf{2}$ & $\mathbf{3}$ \\
\hline Date of cutting & 7 October 1994 & 2 May 1995 & 15 September 1995 \\
Cut & 5 th & 1 st & 4 th \\
Yield $\left(\mathrm{t} \mathrm{DM} \mathrm{ha}{ }^{-1}\right)$ & $2 \cdot 4$ & $4 \cdot 0$ & $3 \cdot 2$ \\
Stage & Vegetative & Vegetative & Early bud \\
Days of conservation & 90 & 76 & 157 \\
Period of consumption & Winter & Summer & Spring \\
\hline
\end{tabular}

Table 2 Main nutritional characteristics [content $\mathrm{g} \mathrm{kg}^{-1} \mathrm{DM}$, except DM $\left(\mathrm{g} \mathrm{kg}^{-1} \mathrm{FM}\right)$ ] of lucerne at cutting, silage at feed-out and hay in the

\begin{tabular}{|c|c|c|c|c|c|c|c|c|c|}
\hline \multirow[b]{2}{*}{ Experiment } & \multicolumn{3}{|c|}{ Herbage at cutting } & \multicolumn{3}{|c|}{ Silage } & \multicolumn{3}{|c|}{ Artificially dried hay } \\
\hline & 1 & 2 & 3 & 1 & 2 & 3 & 1 & 2 & 3 \\
\hline $\mathrm{DM}$ & 220 & 160 & 208 & 550 & 360 & 432 & 850 & 850 & 890 \\
\hline CP & 215 & 249 & 186 & 203 & 212 & 180 & 189 & 184 & 181 \\
\hline NDF & 354 & 354 & 418 & 396 & 385 & 429 & 397 & 403 & 423 \\
\hline $\mathrm{ADF}$ & 311 & 301 & 349 & 342 & 341 & 367 & $\mathrm{ND}$ & ND & 355 \\
\hline Ash & 90 & 94 & 92 & 125 & 141 & 136 & 107 & 140 & 100 \\
\hline
\end{tabular}
three experiments.

DM, dry matter; $\mathrm{CP}$, crude protein; NDF, neutral-detergent fibre; ADF, acid-detergent fibre; ND, not determined. 
Table 3 Chemical and microbial composition of lucerne silages sampled during feeding in peripheral and central zones of the clamps.

\begin{tabular}{|c|c|c|c|c|c|c|}
\hline \multirow[b]{3}{*}{ Zone } & \multicolumn{6}{|c|}{ Experiment } \\
\hline & \multicolumn{2}{|c|}{1} & \multicolumn{2}{|c|}{2} & \multicolumn{2}{|c|}{3} \\
\hline & $\begin{array}{c}\text { Central } \\
(d)^{*}\end{array}$ & $\begin{array}{c}\text { Peripheral } \\
\text { (a b c })\end{array}$ & $\begin{array}{l}\text { Central } \\
\text { (d) }\end{array}$ & $\begin{array}{l}\text { Peripheral } \\
\quad(\mathbf{a} \text { b c c) }\end{array}$ & $\begin{array}{l}\text { Central } \\
\text { (d) }\end{array}$ & $\begin{array}{l}\text { Peripheral } \\
\quad(\text { a b c) }\end{array}$ \\
\hline $\mathrm{DM}\left(\mathrm{g} \mathrm{kg}^{-1} \mathrm{FM}\right)$ & 610 & 508 & 349 & 425 & 425 & 410 \\
\hline Wet bulk density $\left(\mathrm{kg} \mathrm{m}^{-3}\right)$ & 439 & 291 & 834 & 414 & 480 & 293 \\
\hline DM density $\left(\mathrm{kg} \mathrm{m}^{-3}\right)$ & 268 & 148 & 291 & 176 & 204 & 120 \\
\hline $\mathrm{pH}$ & $6 \cdot 0$ & $6 \cdot 0$ & $5 \cdot 4$ & $4 \cdot 7$ & $4 \cdot 8$ & $5 \cdot 7$ \\
\hline Total $\mathrm{N}\left(\mathrm{g} \mathrm{kg}^{-1} \mathrm{DM}\right)$ & 32 & 33 & 34 & 33 & 29 & 27 \\
\hline Ammonia-N $\left(\mathrm{g} \mathrm{kg}^{-1} \mathrm{TN}\right)$ & 41 & 61 & 162 & 94 & 80 & 200 \\
\hline Soluble-N $\left(\mathrm{g} \mathrm{kg}^{-1} \mathrm{TN}\right)$ & 350 & 380 & 720 & 660 & 650 & 580 \\
\hline Lactic acid $\left(\mathrm{g} \mathrm{kg}^{-1} \mathrm{DM}\right)$ & $10 \cdot 0$ & $14 \cdot 3$ & $21 \cdot 2$ & $39 \cdot 2$ & $16 \cdot 0$ & ND \\
\hline Acetic acid ( $\left.\mathrm{g} \mathrm{kg}^{-1} \mathrm{DM}\right)$ & $4 \cdot 1$ & $9 \cdot 2$ & $41 \cdot 5$ & $19 \cdot 3$ & $14 \cdot 0$ & ND \\
\hline Butyric acid ( $\left.\mathrm{g} \mathrm{kg}^{-1} \mathrm{DM}\right)$ & 0 & 0 & 0 & 0 & $0 \cdot 3$ & ND \\
\hline $\begin{array}{l}\text { Clostridia spores } \\
\qquad\left(\log \mathrm{MPN} \mathrm{g}^{-1} \mathrm{FM}\right)\end{array}$ & $2 \cdot 49$ & $2 \cdot 06$ & $1 \cdot 60$ & $1 \cdot 78$ & $1 \cdot 70$ & $2 \cdot 39$ \\
\hline Yeast (log CFU g $\left.{ }^{-1} F M\right)$ & $3 \cdot 79$ & $3 \cdot 46$ & $3 \cdot 00$ & $3 \cdot 15$ & $3 \cdot 30$ & $4 \cdot 55$ \\
\hline Moulds (log CFU g $\left.{ }^{-1} \mathrm{FM}\right)$ & $3 \cdot 66$ & $3 \cdot 30$ & $2 \cdot 95$ & $3 \cdot 00$ & 3.79 & $5 \cdot 75$ \\
\hline
\end{tabular}

FM, fresh matter; DM, dry matter; TN, total nitrogen; MPN, most probable number; CFU, colony forming units; ND, not determined. *See Figure 1 for description of a, b, c, and d.

and the short wilting times, owing to the favourable climatic conditions, achieved the high quality in silages and hays. The limited decrease in CP content and the increase in NDF content from herbage to silage and hay could be ascribed mainly to loss of leaf during wilting. The DM contents of the forages at ensiling were 550, 360, $432 \mathrm{~g} \mathrm{~kg}^{-1}$ in Experiments 1, 2, and 3 respectively. The high DM content in the first experiment was due to the high DM content at cutting and to the very good weather conditions during wilting associated with a low yield.

The increase in the ash content of the silages and hays compared with the fresh forage was due to fermentation losses and to soil contamination during mechanical treatments from cutting to harvesting.

\section{Lucerne silage conservation}

The main chemical and microbial characteristics of the silage in the three experiments, divided into central and peripheral zones of the silo, are reported in Table 3.

The DM content revealed stratification in Experiments 1 and 2, whereas in Experiment 3 the DM content was quite uniform. In Experiment 1, the upper (peripheral) part was wetter than the lower (central) one, owing to the addition of a forage with a higher moisture content to the top of the clamp to improve the consolidation of the silage characterized by a very high DM content at ensiling. In Experiment 2 the stratification was the opposite of that in Experiment 1, because of a longer drying period for the last batches of forage ensiled.
The density values in the central part of the silos were similar to those observed in forages cut with a precisionchop machine (e.g. Rees et al., 1983; Darby and Jofriet, 1993), whereas in the peripheral zones they were not sufficiently high to avoid aerobic deterioration (Williams et al., 1994).

The difference in DM content of the lucerne silage between the layers and experiments influenced fermentation. As found by other researchers, both with laboratory scale silos (Muck, 1987) or with large, commercial silos (Luchini et al., 1997), ammonia-N concentration was inversely related to the DM content of the silage (Figure 2), with the exception of two samples of Experiment 3 taken from the peripheral area ( $a$ and $b$ ), which showed intense aerobic deterioration. In the second experiment the DM content of $360 \mathrm{~g} \mathrm{~kg}^{-1}$ FM reached during wilting was not sufficient to guarantee a good fermentation.

The concentration of soluble- $\mathrm{N}$ was high in Experiments 2 and 3 (720 and $650 \mathrm{~g} \mathrm{~kg}^{-1} \mathrm{TN}$ for the central zones respectively) and, again, inversely correlated to the DM content of the silage. These results agree with the high values reported by Muck (1987) and are higher than the value $\left(500 \mathrm{~g} \mathrm{~kg}^{-1} \mathrm{TN}\right)$ tabulated by the Cornell Net Carbohydrate and Protein System (CNCPS) for an early bloom (350 $\mathrm{g} \mathrm{DM} \mathrm{kg}^{-1}$ ) lucerne silage (Barry et al., 1994). In the first experiment the soluble- $\mathrm{N}$ of the high DM silage was very low and similar to that of hay.

In all the experiments no clostridia development could be detected, as indicated by the low level of spores. The number of yeast and moulds was around 


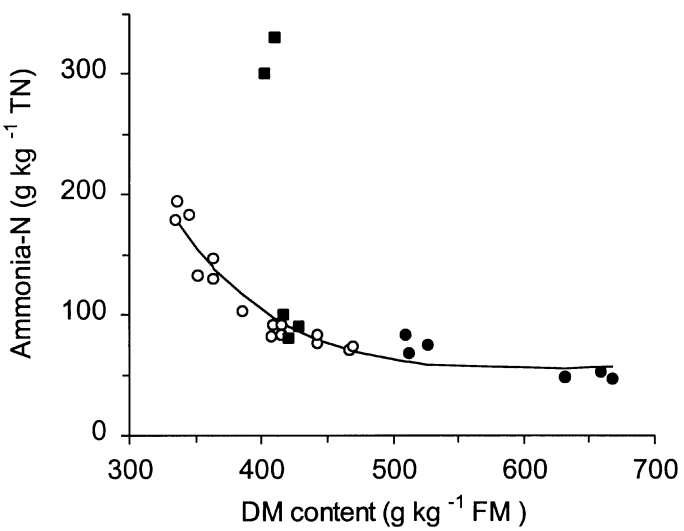

Figure 2 Relationship between ammonia- $\mathrm{N}$ in lucerne silages and DM content (hyperbolic regression, ammonia- $\mathrm{N}=7.2810^{7} \mathrm{DM}^{-2}$ $2 \cdot 4310^{5} \mathrm{DM}^{-1}+257 ; r^{2}=0.922$; the two highest values of Experiment 3 are not included in the regression). Experiment I; $\mathrm{O}$, Experiment 2; $\mathbf{\square}$, Experiment 3.

$3 \log \mathrm{CFU} \mathrm{g}{ }^{-1} \mathrm{FM}$ in all the experiments, excluding the peripheral zones of the third experiment where there was an advanced aerobic deterioration shown by the higher count of yeast and moulds. Pahlow (1991) indicates the threshold of $5 \log \mathrm{CFU} \mathrm{g}{ }^{-1} \mathrm{FM}$ as a critical yeast value for aerobic stability.

\section{Maize silage quality}

The DM content of the silages were typical of maize harvested at the dough stage of maturity in the Po Valley, being 322, 361 and $336 \mathrm{~g} \mathrm{~kg}^{-1}$ in Experiments 1, 2 and 3 respectively (Table 4 ). The chemical composition was similar with a lactic acid content ranging from 51 to $63 \mathrm{~g} \mathrm{~kg}^{-1}$ DM and no butyric acid.

Clostridia spores were always below $10^{3} \mathrm{~g}^{-1}$, indicating no butyric fermentation in the maize silages in the three experiments.

The yeast counts were higher than those observed in lucerne. This confirms, especially as far as Experiments 1 and 2 are concerned, a higher risk of aerobic deterioration spoilage for maize silage than lucerne, as found by other authors (Muck and O'Kiely, 1992; O'Kiely and Muck, 1992). The high yeast count of maize silages is probably due to the low rates of feedingout $\left(10,12\right.$ and $13 \mathrm{~cm} \mathrm{~d}^{-1}$ in Experiments 1, 2 and 3 respectively) and to the interaction with the season of the experiments (higher in Experiment 2 in summer).

\section{Feed intake}

The composition of the rations consumed during the three experiments is reported in Table 5. In the first experiment lucerne was the main component of the ration providing $35 \%$ of the total DM, with maize silage
Table 4 Chemical and microbial composition of the maize silages sampled during feeding in the three experiments.

\begin{tabular}{|c|c|c|c|}
\hline & \multicolumn{3}{|c|}{ Experiment } \\
\hline & 1 & 2 & 3 \\
\hline $\mathrm{DM}\left(\mathrm{g} \mathrm{kg}^{-1} \mathrm{FM}\right)$ & 322 & 361 & 336 \\
\hline $\mathrm{CP}\left(\mathrm{g} \mathrm{kg}^{-1} \mathrm{DM}\right)$ & 85 & 85 & 87 \\
\hline $\mathrm{NDF}\left(\mathrm{g} \mathrm{kg}^{-1} \mathrm{DM}\right)$ & 435 & 414 & 372 \\
\hline $\mathrm{ADF}\left(\mathrm{g} \mathrm{kg}^{-1} \mathrm{DM}\right)$ & 262 & ND & ND \\
\hline $\mathrm{pH}$ & 3.9 & $4 \cdot 1$ & $3 \cdot 9$ \\
\hline Ammonia-N $\left(\mathrm{g} \mathrm{kg}^{-1} \mathrm{TN}\right)$ & 86 & 110 & ND \\
\hline Soluble-N ( $\left.\mathrm{g} \mathrm{kg}^{-1} \mathrm{TN}\right)$ & 509 & 569 & ND \\
\hline Lactic acid ( $\left.\mathrm{g} \mathrm{kg}^{-1} \mathrm{DM}\right)$ & $62 \cdot 7$ & $60 \cdot 5$ & $51 \cdot 0$ \\
\hline Acetic acid $\left(\mathrm{g} \mathrm{kg}^{-1} \mathrm{DM}\right)$ & $21 \cdot 7$ & $34 \cdot 0$ & $15 \cdot 0$ \\
\hline Butyric acid $\left(\mathrm{g} \mathrm{kg}^{-1} \mathrm{DM}\right)$ & 0 & 0 & 0 \\
\hline $\begin{array}{l}\text { Clostridia spores } \\
\left(\log \mathrm{MPN} \mathrm{g}^{-1} \mathrm{FM}\right)\end{array}$ & $2 \cdot 66$ & $2 \cdot 31$ & $2 \cdot 85$ \\
\hline Yeast (log CFU g $\left.{ }^{-1} \mathrm{FM}\right)$ & $5 \cdot 19$ & $5 \cdot 59$ & $4 \cdot 48$ \\
\hline Moulds (log CFU g ${ }^{-1}$ FM) & $3 \cdot 86$ & $4 \cdot 26$ & $4 \cdot 08$ \\
\hline
\end{tabular}

Abbreviations as in Tables 2 and 3.

representing $26 \%$, whereas in the second and third experiments maize and lucerne constituted $36 \%$ and $24-25 \%$ of total DM respectively.

The chemical and microbiological analyses of the rations are reported in Table 6. As expected, the $\mathrm{CP}$ content was lower and the NDF content higher than international feeding standards: $>150 \mathrm{~g} \mathrm{CP}$ and $280 \mathrm{~g}$ NDF per $\mathrm{kg}$ of DM for the cow size and milk yield considered (NRC, 1989). However, this reflects the need to reduce $\mathrm{N}$ excretion, especially in an area with a high concentration of cattle, such as that producing Grana Padano cheese. The net energy for lactation was balanced between treatments and was higher in Experiment 3 to sustain the higher milk yield.

The clostridia spore content of the rations was limited and always below $400 \mathrm{MPN} \mathrm{g}^{-1}\left(2 \cdot 60 \operatorname{log~g~}^{-1}\right)$, and no differences were observed between the treatments and experiments.

The yeast contents of the rations were highest in Experiment $\mathrm{l}$ and lowest in Experiment 2. As the values of the two treatments within each experiment were similar, it is likely that the rather high yeast contents of the rations did not depend primarily on the lucerne forage but mainly on the maize silage that appeared always to have a high yeast content (Table 4).

Individual daily DM intakes of the cows fed lucerne silage or hay were 18.8 and $18 \cdot 5,18 \cdot 0$ and $19 \cdot 0,20 \cdot 5$ and $20 \cdot 1 \mathrm{~kg}$ in Experiments 1, 2 and 3 respectively. The feed intake, similar in the two treatments in Experiments 1 and 3, was slightly lower for the silage treatment in Experiment 2, probably because of the non-optimal fermentation of the lucerne silage in that experiment (see Table 3). 
Table 5 Composition of the individual rations consumed $\left(\mathrm{kg}_{\mathrm{g}}\right.$ fresh matter $\left.\mathrm{d}^{-1}\right)$ in the three experiments. The proportions (\%) of total ration DM are shown in brackets.

\begin{tabular}{|c|c|c|c|c|c|c|}
\hline \multirow[b]{3}{*}{ Treatment } & \multicolumn{6}{|c|}{ Experiment } \\
\hline & \multicolumn{2}{|c|}{1} & \multicolumn{2}{|c|}{2} & \multicolumn{2}{|c|}{3} \\
\hline & Silage & Hay & Silage & Hay & Silage & Hay \\
\hline Lucerne silage & $12 \cdot 0$ & - & $11 \cdot 3$ & - & $11 \cdot 1 \quad(24)$ & - \\
\hline Lucerne hay & - & $7 \cdot 4(34)$ & - & $5 \cdot 5 \quad(25)$ & - & $5 \cdot 4(24)$ \\
\hline Maize silage & $15 \cdot 0 \quad(26)$ & $15 \cdot 0$ & 18.5 & $19 \cdot 0$ & $22 \cdot 2(36)$ & $22 \cdot 6$ \\
\hline Grass hay & $2 \cdot 0(9)$ & $2 \cdot 0(9)$ & $1.5(7)$ & $1.6(7)$ & $2 \cdot 2(9)$ & $2 \cdot 2(9)$ \\
\hline Concentrate & $6.5(30)$ & $6 \cdot 5(31)$ & $6 \cdot 8 \quad(33)$ & $7 \cdot 0 \quad(32)$ & $7 \cdot 2(31)$ & $7 \cdot 0 \quad(31)$ \\
\hline
\end{tabular}

Table 6 Main chemical and microbiological parameters of the rations fed in the three experiments.

\begin{tabular}{|c|c|c|c|c|c|c|}
\hline \multirow[b]{3}{*}{ Treatment } & \multicolumn{6}{|c|}{ Experiment } \\
\hline & \multicolumn{2}{|c|}{1} & \multicolumn{2}{|c|}{2} & \multicolumn{2}{|c|}{3} \\
\hline & Silage & Hay & Silage & Hay & Silage & Hay \\
\hline \multicolumn{7}{|l|}{ Chemical composition } \\
\hline $\mathrm{CP}\left(\mathrm{g} \mathrm{kg}^{-1} \mathrm{DM}\right)$ & 143 & 138 & 138 & 137 & 145 & 149 \\
\hline $\mathrm{NDF}\left(\mathrm{g} \mathrm{kg}^{-1} \mathrm{DM}\right)$ & 410 & 426 & 368 & 386 & 338 & 336 \\
\hline NEL $\left(M^{\prime} k g^{-1} \mathrm{DM}\right)$ & $6 \cdot 40$ & $6 \cdot 38$ & $6 \cdot 44$ & $6 \cdot 40$ & $6 \cdot 70$ & 6.75 \\
\hline \multicolumn{7}{|l|}{ Microbiological composition } \\
\hline Clostridia spores $\left(\log \mathrm{MPN}^{-1} \mathrm{FM}\right)$ & $2 \cdot 24$ & $2 \cdot 20$ & $2 \cdot 09$ & $2 \cdot 60$ & $2 \cdot 35$ & $2 \cdot 21$ \\
\hline Yeast (log CFU g $\left.{ }^{-1} \mathrm{FM}\right)$ & 6.57 & 6.51 & $5 \cdot 30$ & $5 \cdot 20$ & 6.01 & $5 \cdot 76$ \\
\hline
\end{tabular}

NEL, net energy for lactation; other abbreviations as in Tables 2 and 3.

\section{Faeces}

The spore contents $\left(\mathrm{MPN} \mathrm{g}^{-1}\right)$ of the faeces from cows fed lucerne silage and lucerne hay were 362 and 342, 188 and 189, 558 and 76 in Experiments 1, 2, and 3 respectively. There was no difference between treatments in Experiments 1 and 2, whereas in Experiment 3 lucerne silage produced significantly higher $(P<0.01)$ spore counts in the faeces. However, all the values found were very low compared with previous studies (Gouet and Contrepois, 1971; Crovetto et al., 1990; Colombari and Fantuzzi, 1991) in which concentrations of $10^{5}-10^{6}$ spores per gram were found when the rations included silages with a high clostridial spore count. The low values in our experiments could be attributed to the absence of clostridia growth in the silage due to the high DM content obtained by wilting and to the technique of ensiling.

\section{Milk yield and composition}

The milk yield and composition in the three experiments are reported in Table 7 . The milk yield was similar for both treatments within each experiment, independent of the production level, and the DM ratio between the maize and lucerne silage. Milk yield in Experiment 3 was higher because of the earlier stage of lactation of the animals. The hay-fed cows had a slightly but significantly higher milk yield in Experiment 2, probably owing to the higher feed intake. Similarly to our results, no significant differences in milk yield $\left(\mathrm{kg} \mathrm{d}^{-1}\right)$ of cows fed early-cut lucerne silage or hay have been found by other researchers: $30 \cdot 1$ vs. $30 \cdot 0$ (Nelson and Satter, 1992b); 35.1 vs. 35.7, average of four experiments (Vagnoni and Broderick, 1997).

In Experiments 2 and 3, the protein content of milk was slightly but significantly decreased and the milk fat content significantly increased with the lucerne silage. This is consistent with the results of other studies (Nelson and Satter, 1992b; Broderick, 1995; Vagnoni and Broderick, 1997) in which 300-400 $\mathrm{g} \mathrm{kg}^{-1}$ DM lucerne silage was fed to lactating cows and compared with lucerne hay. The increase in fat content of milk with silage may be attributable to a greater fibre digestion (Broderick, 1995) with consequent higher ruminal synthesis of fat precursors such as butyrate 
Table 7 Milk yield, composition, nitrogenous fractions, renneting properties, and microbiological characteristics of the milk in the three experiments.

\begin{tabular}{|c|c|c|c|c|c|c|c|c|c|c|c|c|}
\hline \multirow[b]{3}{*}{ Treatment } & \multicolumn{12}{|c|}{ Experiment } \\
\hline & \multicolumn{4}{|c|}{1} & \multicolumn{4}{|c|}{2} & \multicolumn{4}{|c|}{3} \\
\hline & Silage & Hay & s.e.m. & $P$ & Silage & Hay & s.e.m. & $P$ & Silage & Hay & s.e.m. & $P$ \\
\hline \multicolumn{13}{|l|}{ Milk yield and composition } \\
\hline Milk yield $\left(\mathrm{kg} \mathrm{d}^{-1}\right)$ & $21 \cdot 0$ & $20 \cdot 8$ & $0 \cdot 22$ & NS & $20 \cdot 0$ & $20 \cdot 6$ & $0 \cdot 12$ & $* *$ & $28 \cdot 4$ & $27 \cdot 9$ & $0 \cdot 18$ & NS \\
\hline Protein $\left(\mathrm{g} \mathrm{kg}^{-1}\right)$ & $33 \cdot 3$ & $33 \cdot 1$ & $0 \cdot 15$ & NS & $30 \cdot 6$ & $31 \cdot 0$ & 0.09 & $* * *$ & $33 \cdot 7$ & $34 \cdot 1$ & $0 \cdot 10$ & $* *$ \\
\hline Fat $\left(\mathrm{g} \mathrm{kg}^{-1}\right)$ & $40 \cdot 7$ & $40 \cdot 5$ & $0 \cdot 35$ & NS & $37 \cdot 8$ & $37 \cdot 0$ & $0 \cdot 20$ & $* *$ & $36 \cdot 1$ & $34 \cdot 9$ & $0 \cdot 23$ & $* *$ \\
\hline Lactose $\left(\mathrm{g} \mathrm{kg}^{-1}\right)$ & $50 \cdot 0$ & $49 \cdot 7$ & $0 \cdot 15$ & NS & $50 \cdot 4$ & $50 \cdot 1$ & $0 \cdot 80$ & * & $50 \cdot 5$ & $50 \cdot 4$ & $0 \cdot 07$ & NS \\
\hline $\operatorname{SCC}\left(\log \mathrm{ml}^{-1}\right)$ & $5 \cdot 31$ & $5 \cdot 31$ & $4 \cdot 38$ & NS & $5 \cdot 10$ & $5 \cdot 14$ & $4 \cdot 10$ & NS & $5 \cdot 30$ & $5 \cdot 33$ & $4 \cdot 12$ & NS \\
\hline \multicolumn{13}{|l|}{ Nitrogenous fractions } \\
\hline Casein $\mathrm{N}\left(\mathrm{g} \mathrm{kg}^{-1} \mathrm{~N}\right)$ & 763 & 763 & $3 \cdot 3$ & NS & 766 & 764 & $2 \cdot 0$ & NS & 770 & 770 & $2 \cdot 8$ & NS \\
\hline Non-protein $\mathrm{N}\left(\mathrm{g} \mathrm{kg}^{-1} \mathrm{~N}\right)$ & 57 & 57 & $2 \cdot 2$ & NS & 50 & 49 & $1 \cdot 8$ & NS & 52 & 55 & $2 \cdot 3$ & NS \\
\hline Whey protein $\mathrm{N}\left(\mathrm{g} \mathrm{kg}^{-1} \mathrm{~N}\right)$ & - & - & - & - & 183 & 187 & $3 \cdot 7$ & NS & 179 & 175 & $3 \cdot 4$ & NS \\
\hline Urea $\left(\mathrm{mg} \mathrm{l}^{-1}\right)$ & 210 & 210 & $10 \cdot 4$ & NS & 270 & 270 & $10 \cdot 1$ & NS & 264 & 276 & $12 \cdot 3$ & NS \\
\hline \multicolumn{13}{|l|}{ Renneting properties } \\
\hline Acidity $\left({ }^{\circ} \mathrm{SH} 50 \mathrm{ml}^{-1}\right)$ & $3 \cdot 46$ & $3 \cdot 41$ & $0 \cdot 032$ & NS & $3 \cdot 32$ & $3 \cdot 30$ & 0.032 & NS & $3 \cdot 33$ & $3 \cdot 33$ & $0 \cdot 084$ & NS \\
\hline$r(\min )$ & $15 \cdot 3$ & $15 \cdot 6$ & $0 \cdot 26$ & NS & $16 \cdot 3$ & $16 \cdot 4$ & $0 \cdot 40$ & NS & $17 \cdot 7$ & $17 \cdot 2$ & $0 \cdot 31$ & NS \\
\hline$k_{20}(\min )$ & $9 \cdot 1$ & $9 \cdot 2$ & $0 \cdot 28$ & NS & $12 \cdot 7$ & $11 \cdot 9$ & $0 \cdot 38$ & NS & $8 \cdot 9$ & $8 \cdot 4$ & $0 \cdot 25$ & NS \\
\hline$a_{30}(\mathrm{~mm})$ & $28 \cdot 5$ & $28 \cdot 2$ & $1 \cdot 21$ & NS & $19 \cdot 9$ & $20 \cdot 1$ & $0 \cdot 91$ & NS & $26 \cdot 8$ & $29 \cdot 9$ & $0 \cdot 50$ & * \\
\hline \multicolumn{13}{|l|}{ Microbiological characteristics } \\
\hline $\mathrm{SBC}\left(\log \mathrm{ml}^{-1}\right)$ & 4.58 & $4 \cdot 62$ & $0 \cdot 103$ & NS & $5 \cdot 37$ & $5 \cdot 12$ & $0 \cdot 101$ & NS & $4 \cdot 60$ & $4 \cdot 76$ & $0 \cdot 197$ & NS \\
\hline Proteolytic bacteria $\left(\log \mathrm{ml}^{-1}\right)$ & $3 \cdot 13$ & $3 \cdot 11$ & $0 \cdot 109$ & NS & 3.59 & $3 \cdot 72$ & $0 \cdot 052$ & NS & $2 \cdot 81$ & 3.00 & $0 \cdot 216$ & NS \\
\hline Coli bacteria $\left(\log \mathrm{ml}^{-1}\right)$ & $1 \cdot 90$ & $1 \cdot 85$ & $0 \cdot 040$ & NS & $2 \cdot 81$ & $2 \cdot 82$ & $0 \cdot 116$ & NS & $2 \cdot 41$ & $2 \cdot 49$ & $0 \cdot 237$ & NS \\
\hline Lactic acid bacteria $\left(\log \mathrm{ml}^{-1}\right)$ & $3 \cdot 10$ & $3 \cdot 04$ & 0.059 & NS & $3 \cdot 83$ & $3 \cdot 80$ & 0.032 & NS & $3 \cdot 62$ & 3.56 & $0 \cdot 229$ & NS \\
\hline Clostridia spores $\left(\log l^{-1}\right)$ & $2 \cdot 16$ & $2 \cdot 06$ & $0 \cdot 082$ & NS & $2 \cdot 53$ & $2 \cdot 62$ & 0.050 & NS & $2 \cdot 14$ & $1 \cdot 86$ & $0 \cdot 192$ & NS \\
\hline
\end{tabular}

SCC, somatic cell count; $r$, time required to start clotting; $k_{20}$, time to reach a standard clot consistency; $a_{30}$, consistency of the clot after 30 min from the beginning of clotting; SBC, standard bacterial count.

Within rows and experiment, NS, not significant; ${ }^{*} P \leq 0 \cdot 05 ;{ }^{* *} P \leq 0 \cdot 01 ; * * * P \leq 0 \cdot 001$.

(Vagnoni and Broderick, 1997). Among volatile fatty acids, butyrate absorption through the rumen wall is mostly influenced by rumen acidity, and reaches the maximum rates at a low pH (Pitt et al., 1996).

The decrease in milk protein content in the silage treatment could be due to inadequate intestinal absorbed protein which, in turn, could be ascribed, on the one hand, to the very limited rumen undegradable protein (RUP) content of lucerne silage (10\%, Makoni et al., 1991) and, on the other hand, to an excess of soluble- $\mathrm{N}$ with consequent excessive ammonia- $\mathrm{N}$ and an unbalanced ratio between the latter and amino peptide N. Microbial protein synthesis is normally lower with lucerne silage than with lucerne hay, probably because of the smaller microbial uptake of $\mathrm{N}$ from amino acids and peptides (Petelkova and Broderick, 1996); this finding confirms the study by Van Kessel and Russell (1996), which has shown that when the energy supply in the rumen is high the highest rates of microbial protein synthesis can be attained with a supply of amino peptide $\mathrm{N}$.
Lactose content and SCC were practically constant over the treatments and experiments.

There was no significant effect of treatment on the nitrogenous fractions of milk (Table 7). The urea content in Experiment 1 was lower than that of the other two experiments. For the 'silage' rations this can be explained by the much lower $\mathrm{N}$ solubility of lucerne silage in Experiment $1(35 \%)$ than in Experiments 2 $(72 \%)$ and $3(65 \%)$ (see Table 3$)$.

However, the milk urea contents were satisfactory for Experiments 2 and 3, always being below $300 \mathrm{mg} \mathrm{l}^{-1}$ milk. It should be noted that the low urea content of milk was achieved despite the high proportion of $\mathrm{N}$ from lucerne silage, which is more than $50 \%$ soluble (see Table 3), and also because of the low protein level of the rations.

\section{Milk-renneting properties and microbiology}

The renneting properties and microbiological characteristics of the milk are shown in Table 7 . There were no 
significant treatment effects for the parameters investigated, except for the greater clot consistency $\left(a_{30}\right)$ of the milk produced by the lucerne hay-fed cows in Experiment 3. When considering the differences between Experiment 2 conducted in the warm season and those carried out in the cold season (Experiments 1 and 3), it can be seen that the latter (characterized by higher milk protein contents) showed other positive characteristics such as a shorter time to reach the $20-\mathrm{mm}$ reference clot consistency $\left(k_{20}\right)$ and a stronger clot consistency after $30 \mathrm{~min}$ from the beginning of clotting $\left(a_{30}\right)$.

The microbiological characteristics of the milk did not differ between treatments in any experiment; the levels of SBC, proteolytic, coli and lactic acid bacteria, and clostridia spores were lower in Experiments 1 and 3 than in Experiment 2. This indicates that the season (cold or warm) had a much higher effect than the conservation technique (ventilated hay vs. silage) on the microbiological content of milk.

The inclusion of lucerne silage in the ration did not increase the spore content of milk, and in each experiment the spore count was always very low $(<400$ per litre) fulfilling the requirements for a top milk quality (Bottazzi and Battistotti, 1978) destined for the production of Grana Padano cheese.

\section{Cheese quality}

The trade classification of the thirty-two cheeses (sixteen per treatment) of the Grana Padano produced from the milk of Experiment 3 showed that all the cheeses were commercially good and no third-choice cheese was recorded for either group; only one cheese of the group fed on the silage treatment was evaluated as being of second choice. The second-choice cheese was analysed by gas chromatography to identify the origin of the damage; no butyric acid was detected, confirming that no clostridial development had taken place, although evidence of a heterolactic fermentation was found.

\section{Conclusions}

Lucerne forage, cut at an early stage (vegetative or early bud), harvested and chopped with a self-loading wagon, can be successfully ensiled in small clamps even with a high DM content (around 50\%), provided that accurate sealing and compaction of the forage, and a correct feedout rate are carried out in order to avoid risks of aerobic deterioration because of its high porosity.

The data obtained indicate that the substitution in the ration of lucerne silage $(23-35 \%$ of ration DM) for high-quality lucerne hay did not change the milk yield and milk composition from a practical point of view. The same holds true for the milk nitrogenous fractions and the milk renneting properties.
The quality of the Grana Padano cheese after 12 months of maturation was very good and not influenced by the inclusion of lucerne silage into the ration. This is likely to be ascribed to the low spore content of the milk which, in turn, depends on the low spore contamination of the silages used.

The use of good-quality lucerne silage can increase the proportion of home-grown forage, reduce the amount of the purchased feeds and has no negative repercussions on the quantitative and qualitative milk production and subsequent cheese quality.

\section{Acknowledgments}

The authors would like to thank Donato Costa and Donatella Melani of the 'Istituto Superiore Lattiero Caseario' of Mantova for the chemical and microbiological analyses. The work was supported by the 'Assessorato Agricoltura' of the Regione Lombardia.

\section{References}

Acutis M., Borreani G. and Ciotti A. (1994) Prewilting of lucerne for ensiling: an empirical model. In: 't Mannetje L. and Frame J. (eds) Proceedings of the 15th General Meeting of the European Grassland Federation, Wageningen, the Netherlands. pp. 137-141.

Andrieu J. and Demarquilly C. (1987) Valeur nutritive des fourrages: tables et prévision. Alimentation des ruminantes: rèvision des systèmes et des tables de l'INRA. (Nutritive value of forages: tables and predictions. Ruminant nutrition: revision of the systems and tables of the INRA). Bulletin Technique, 70, 61-73.

Annib ALdi S. (1969) Silage feeding and Parmesan cheese making. Proceedings of the 3rd General Meeting of the European Grassland Federation, Braunschweig, Germany. pp. 303-305.

Barry M.C., Fox D.G., Tylutki T.P., Pell A.N., O'Connor J.D., Sniffen C.J. and Chalupa W. (1994) A Manual for Using the Cornell Net Carbohydrate and Protein System for Evaluating Cattle Diets. Ithaca, NY: Cornell Cooperative Extension. Animal Science Department.

Borreani G., Valente M.E., Peiretti P.G., Canale A. and Ciотті A. (1996) Evolution of ensilability characteristics, nutritional values, and yield in the first and second growth cycles of lucerne cv. Equipe and Boreal. In: Parente G, Frame J. and Orsi S. (eds) Grassland and Land Use Systems. Proceedings of the 16th General Meeting of the European Grassland Federation, Grado, Italy. pp. 383-387.

Bотtazzi V. and Batтіsтотті B. (1978) Indicazioni per il controllo del gonfiore tardivo del formaggio grana (Notes about the control of late blowing in Grana cheese). Scienza e Tecnica Lattiero-Casearia, 29, 313-325.

Broderick G.A. (1985) Alfalfa silage or hay versus corn silage as the sole forage for lactating dairy cows. Journal of Dairy Science, 68, 3262-3271. 
Broderick G.A. (1995) Performance of lactating dairy cows fed either alfalfa silage or alfalfa hay as the sole forage. Journal of Dairy Science, 78, 320-329.

Byrne E. and Power R. (1974) Determination of ammonia nitrogen in animal slurries by ammonia electrode. Communications in Soil Science and Plant Analysis, 5, 51.

Canale A., Valente M.E. and Ciotti A. (1984) Determination of volatile carboxylic acids $\left(\mathrm{C}_{1}-\mathrm{C}_{5 \mathrm{i}}\right)$ and lactic acid in aqueous acid extracts of silage by high performance liquid chromatography. Journal of the Science of Food and Agriculture, 35, 1178-1182.

Ciotti A., Canale A., Valente M.E. and Delmastro R. (1985) La tecnica dell'insilamento nella valorizzazione della coltura dell'erba medica (Ensiling methods for improving the lucerne crop). Rivista di Agronomia, 19, 225-230.

Colombari G. and Fantuzzi U. (1991) Insilato, spore di clostridi nelle feci e nel latte e qualità del formaggio Grana: nuove significative esperienze (Silage, clostridia spores in faeces and milk and Grana cheese quality: new important experiences). Scienza e Tecnica Lattiero-Casearia, 42, 344-359.

Contarini G., Zucchetti S., Amelotti G. and Toppino P.M. (1989) Metodiche analitiche e gascromatografiche per la valutazione della frazione acidica libera nei prodotti lattiero-caseari (Analytical and gas chromatographic methods for the evaluation of the free acidic fraction of dairy products). La Rivista Italiana delle Sostanze Grasse, 64, 561-566.

Crovetto G.M., Rapetti L., Sandrucci A., Succi G. and Lodi R. (1990) Indagine preliminare sul contenuto di spore di clostridi butirrici presenti nell'alimento, nel liquido ruminale, nelle feci e nel latte della bovina (Preliminary research on the presence of anaerobic spore-formers in feed, rumen fluid, faeces and milk of the cow). In: Greppi G.F. (ed.) Proceedings of 25th Simposio Internazionale Di Zootecnia, Milano, Italy. pp. 129-137.

DARBy D.E. and Jofriet J.C. (1993) Density of silage in horizontal silos. Canadian Agricultural Engineering, 35, 275-280

Goering H.K. and Van Soest P.J. (1970) Forage Fiber Analyses (Apparatus, Reagents, Procedures and Some Application). Agricultural Handbook no. 379. Washington, DC: USDA-ARS.

Gouet P. and Bergère J.L. (1973) Ensilage et gonflement butyrique des fromages (Ensiling and butyric blowing in cheese). Fourrages, 56, 87-137.

Gouet P. and Contrepois M. (1971) Comportement des spores de bactéries anaérobies fermentant le lactate dans le tractus digestif du ruminant. I. Variations avec le régime de la concentration en spores dans le rumen et les fèces (Behaviour of the lactate-fermenting spores of the anaerobic bacteria in the ruminant digestive tract. I. Variations of the concentration of spores according to diets). Annales de Biologie Animale, Biochimie, Biophysique, 11, 129-138.

Krishnamoorthy U.C., Muscato T.V., Sniffen C.J. and VAN Soest P.J. (1982) Nitrogen fractions in selected feedstuffs. Journal of Dairy Science, 65, 217-225.
Luchini N.D., Broderick G.A., Muck R.E., Makoni N.F. and Vetter R.L. (1997) Effect of storage system and dry matter content on the composition of alfalfa silage. Journal of Dairy Science, 80, 1827-1832.

MAKoni N.F., Shelford J.A. and Fisher L.J. (1991) The rate and extent of silage nitrogen degradation in the rumen as influenced by wilting and duration of regrowth. Canadian Journal of Animal Science, 71, 245-252.

Makoni N.F., Shelford J.A. and Fisher L.J. (1994) Initial rates of degradation of protein fractions from fresh, wilted and ensiled alfalfa. Journal of Dairy Science, 77, 1598-1603.

MARSH R. (1979) The effects of wilting on fermentation in the silo and on the nutritive value of silage. Grass and Forage Science, 34, 1-10.

Marten G.C., Buxton D.R. and Barnes R.F. (1988) Feeding value (Forage quality). In: Hanson A.A., Barnes D.K. and Hill R.R. (eds) Alfalfa and Alfalfa Improvement. Madison, WI, USA: American Society of Agronomy, Crop Science Society of America, Soil Science Society of America. pp. 463-484.

Muck R.E. (1987) Dry matter level effects on alfalfa silage quality: I. Nitrogen transformations. Transactions of the American Society of Agricultural Engineering, 30, 7-14.

Muck R.E. and O'KieLY P. (1992). Aerobic deterioration of lucerne (Medicago sativa) and maize (Zea mais) silages. Effects of fermentation products. Journal of the Science of Food and Agriculture, 59, 145-149.

Nelson W.F. and Satter L.D. (1992a) Impact of alfalfa maturity and preservation method on milk production by cows in early lactation. Journal of Dairy Science, 75, 15621570.

Nelson W.F. and SAtter L.D. (1992b) Impact of stage of maturity and method of preservation of alfalfa on digestion in lactating dairy cows. Journal of Dairy Science, 75, 1571-1580.

NRC (1989) Nutrient Requirements of Dairy Cattle, 6th revised edn. Washington: National Academy Press.

O'Kiely P. and Muck R.E. (1992). Aerobic deterioration of lucerne (Medicago sativa) and maize (Zea mais) silages. Effects of yeasts. Journal of the Science of Food and Agriculture, 59, 139-144.

PAHLOW G. (1991) Role of microflora in forage conservation. In: Pahlow G. and Honig H. (eds) European Grassland Federation. Proceedings of a Conference on Forage Conservation Towards 2000, Braunschweig, Germany. pp. 26-36.

Paterson J.A., Belyea R.L., Bowman J.P., Kerley M.S. and Williams J.E. (1994) The impact of forage quality and supplementation regimen on ruminant animal intake and performance. In: Fahey G.C. (ed.) Forage Quality, Evaluation and Utilization. Madison, WI, USA: American Society of Agronomy, Crop Science Society of America, Soil Science Society of America. pp. 59-114.

Petelkova V.D. and Broderick G.A. (1996) In vitro ruminal degradation and synthesis of protein on fractions extracted from alfalfa hay and silage. Journal of Dairy Science, 79, 612-619.

Pitt R.E., Van Kessel J.S., Fox D.G., Pell A.N., Barry M.C. and Van Soest P.J. (1996) Prediction of ruminal 
volatile fatty acids and $\mathrm{pH}$ within the Net Carbohydrate and Protein System. Journal of Animal Science, 74, 226-244.

Rees D.V.H., Audsley E. and Neale M.A. (1983) Some physical properties that affect the rate of diffusion of oxygen into silage. Journal of Agricultural Science, Cambridge, 100, 601-605.

SAS Institute (1994) SAS/STAT, User's guide, Release 6.10. Cary, NC: SAS Institute.

Spoelstra S.F. (1984) Some Methods to Evaluate the Role of Clostridia in Silage. Intern Rapport Institute for Feeding and Nutrition-DLO no. 168. Lelystad, the Netherlands.

Sprent J.I. and 't MannetJe L. (1996) The role of legumes in sustainable farming systems: past, present and future. In: Younie D. (ed.) Legumes in Sustainable Farming Systems. Occasional Symposium No. 30, British Grassland Society. pp. 2-14.

Stadhouders J. and Jørgensen K. (1990) Prevention of the contamination of raw milk by a hygienic milk production. Bulletin of the International Dairy Federation, 251, 32-36.

Stadhouders J. and Spoelstra S.F. (1990) Prevention of the contamination of raw milk by making a good silage. Bulletin of the International Dairy Federation, 251, 24-31.

TAMmingA S. (1992) Nutrition management of dairy cows as a contribution to pollution control. Journal of Dairy Science, 75, 345-357.

TAMminga S. (1996) A review on environmental impacts of nutritional strategies in ruminants. Journal of Animal Science, 74, 3112-3124.
Tarodo De La Fuente B., Alais C. and Frentz R. (1969) Etude de la coagulation du lait par la présure et la synérèse de coagulum par la méthode thrombélastographique (Study of the coagulation of milk by rennet and of synaeresis of the coagulum using a trombelastographic method). Lait, 49, 400-416.

VAGNoNi D.B. and Broderick G.A. (1997) Effects of supplementation of energy on ruminally undegraded protein to lactating cows fed alfalfa hay or silage. Journal of Dairy Science, 80, 1703-1712.

Van Kessel J.S. and Russell J.B. (1996) The effect of amino nitrogen on the energetics of ruminal bacteria and its impact on energy spilling. Journal of Dairy Science, 79, $1237-1243$.

Van Vuuren A.M., Huhtanen P. and Dulphy J.-P. (1995) Improving the feeding and health value of ensiled forages. In: Journet M., Grenet E., Farce M.-H., Thériez M. and Demarquilly C. (eds) Recent Developments in the Nutrition of Herbivores. Proceedings of the 4th International Symposium on the Nutrition of Herbivores, Clermont-Ferrand, France. pp. 279-307.

Williams A.G., Lowe J.F. and Rees D.V.H. (1994) The permeability and porosity of grass silage as affected by dry matter content in grass silage. Journal of Agricultural Engineering Research, 59, 133-140.

Wilman D., Foulkes G.R. and Givens D.I. (1996) The rate and extent of cell-wall degradation in vitro for 40 silages varying in composition and digestibility. Animal Feed Science and Technology, 63, 111-122.

Woolford M.K. (1990) The detrimental effects of air on silage. Journal of Applied Bacteriology, 68, 101-116. 